\title{
ASSESSMENT FOR SUSTAINABILITY OF GREEN MARKETING IN BUSINESS WORLD: A CASE STUDY FOR AN ENTERTAINMENT ACTIVITY
}

\author{
DOI: 10.17261/Pressacademia.2018.876 \\ PAP- V.7-2018(29)-p.176-180
}

\section{Aysenur Erdil}

Anadolu-Marmara University, Istanbul, Turkey.

erdil.aysenur@gmail.com, ORCID: 0000-0002-6413-7482

To cite this document

Erdil, A. (2018). Assessment for sustainability of green marketing in business world: a case study for an entertainment activity. PressAcademia Procedia (PAP), V.7, p.176-180

Permemant link to this document: http://doi.org/10.17261/Pressacademia.2018.876

Copyright: Published by PressAcademia and limited licenced re-use rights only.

\begin{abstract}
Purpose- This study aims to organize and provide a social activity such as carnival as clearly as possible and this activity supports to distinguish, divide the amount of waste from landfills according to the recycling, reusing, defining composting and components of biodegradation food marketing and services.

Methodolog- Tthe amounts of clean energy alternatives might have been decided to use-consume for facilities of firm in this scope of research.. Every alternative has a specific price, gain of energy and Public Relations. Multiple criteria decision making were applied to test the hypotheses. This is an optimization issue. It can be thought of as an extension or generalization of linear programming to handle multiple, normally conflicting objective values.

Findings- The results according to the environmental situation, between the energy alternatives, every energy set has a Public relations value, cost, and gain of energy. the problem was modeled due to the goal programming concept. The optimum result will be set according to the calculations of goal programming programme.

Conclusion- In this research, the literature on green marketing and concepts of this issue are presented. Before application of this subject, an overview of green marketing is submitted. This topic was provided and supported the budget for environmental friendly activates with a new green marketing perspective.
\end{abstract}

Keywords: Business, climate change, environment, green marketing, sustainability, strategy.

JEL Codes: Q54, Q56, E32, L10

\section{INTRODUCTION}

Green marketing (GM) subsumes greening products as well as greening firms. In addition to manipulating the 4Ps (product, price, place, and promotion) of the traditional marketing mixture, it requires a careful understanding of public policy. GM is the marketing of goodsproducts activities which are assumed to be eco-friendly due to the international marketing organization (Young et al., 2010; Singhand Bansal, 2012). Nowadays, more significant and ecological oriented objectives depend on environmental topics such as global warming. Climate change is really vital and attending issue for population and households all over the world to take precautions and take action in decreasing the occasions of the sustaining universal warming crisis' situations. If much more corporations have applied forms of green strategies, the majority issues of environment can be decreased and global ecological crisis can be prevented particularly. In order to prevent and decrease the effect of climate change in terms of business, companies can take precaution such as following environmental production and marketing policy. For instance, green production and green marketing are some of these policies-strategies of firms (Lee, 2009, Young et al., 2010; Mahesh and Ganapathi, 2012). Companies must understand and give the importance of sustaining green and construct enterprise according to the level of green strategies which is the best convenient for their business, sectors. The study aims to provide Carnival a green as possible with using green marketing concept. Therefore this issue supports to have solutions to youth carnival's problems as Entertainment Activity about going green (Mostafa, 2007; Chen and Chai, 2010; Singh and Bansal, 2012).

\section{LITERATURE REVIEW}

\subsection{Green Marketing Strategies}

Marketing literature on greening products/firms builds on both the societal and social marketing research. Societal marketing implies that organizations (governments, businesses, and non-profits) need to determine the needs of target markets and to deliver the desired satisfaction in a way that enhances the consumer's and the society' well-being. Social marketing focuses on designing and implementing programs that increase the acceptability of a social idea, cause or practice in target groups (Laroche et al., 2002; Mahesh and Ganapathi, 2012). Industry Green Criteria are "eliminating trash, composting food items, recycling takes back, using recycled\&organic products, clean 
energy, carbon offsetting, social responsibility, traffic problems and transportation methods. The research on these criteria and possible solutions can be explained (Mendleson and Michael, 1195; Young, et al., 2010) Green marketing also ties closely issues of industrial ecology and environmental sustainability such as extended producer's liability, life-cycle analysis, material use and resource flows, and ecoefficiency. Thus, the issue of green marketing is vast, having important implications for business strategy and public policy. Firms can be green themselves in three ways: value-addition processes (firm level), management systems (firm level) and products (product level) Greening the value-addition processes could entail redesigning them, eliminating some of them, modifying technology and inducting new technology-all with the objective of reducing the environmental impact aggregated for all stages. Firms could adopt management systems that create conditions for reducing the environmental impact of value-addition processes. A good example is the Responsible Care program of the chemical industry which establishes systems to promote environmental, health and safety objectives. However, management systems' efficacy for greening value-addition processes is difficult to quantify if they are nit accompanies by performance measures (Karl and Thomas, 1976). The third greening strategy pertains to products. This could take place in the following ways: (i) repair-extend the life of a product by repairing its parts; (ii) recondition-extend the life of a product by significantly overhauling it; (iii) remanufacture- the new product is based on old ones; (iv) reuse-design a product so that it can be used multiple times (v) recycled-products can be reprocessed and converted into raw material to be used in another or the same product and (vi) reduce-even though the product uses less raw material or generates less disposable waste. Marketing Green believes that there are five actions that define green brand leaders. These five actions need to be considered by companies looking to green their brands (McDaniel and David, 1993; Mendleson and Michael, 1995; Singh and Bansal, 2012; Khosla, 2012): (i)Being accountable: Companies should acknowledge that environmental issues such as climate change are real and that despite good intentions, they are part of the problem. At this point, businesses are likely to alienate few consumers with such a statement and can begin to attract the growing group of consumers looking for green brand leadership. (ii)Being Transparent: More and more, leading brands are providing public disclosures of their environmental and social impact. (iii)Being credible: Today, consumers are skeptical; too many companies have tried to greenwash hollow environmental efforts. A such, companies must work hard to build credibility and earn consumer trust over time. One way for a company to do so is to first green its internal operations, followed by its products and services and then its marketing communications. This way, companies ensure that they take responsibility for their own actions before encouraging consumers to do so with their products or through their messaging. (iv)Being an enabler: Leading brands should recognize that consumer expectations have changed. It is not enough for a company to green its products; consumers expect the products that they purchase to help reduce the environmental impact in their own lives too. (v) Being visionary: Visionaries are willing to make bold decisions that redefine their strategy or reshape industry dynamics. Today, there are many emerging green visionaries.

Increasingly, companies recognize that environmental issues can impact brand value. In response, leading brands are increasingly incorporating brand metrics into their evaluation criteria for green investments; they are also taking action to green their operations, products and marketing communications. Smart brand marketers should think twice about simply focusing on near-term green revenue and cost savings opportunities; the path for sustainable growth needs to also start with greening the brand (Mendleson and Michael, 1995).

\subsection{Determining and Supporting Green Solutions}

(a) Clean Energy: Renewable energy is energy which comes from natural resources such as sunlight, wind, rain, tides and geothermal heat which are renewable. Biodiesel can be produced from animals fats, vegetable oils or recycled greases. Biodiesel can be used as a fuel for vehicles in its pure structure-form but it is usually used as a diesel additive to reduce levels of particulates, carbon monoxide and hydrocarbons from diesel-powered vehicles (Cift and Okutan, 2013; Renewable Energy World, 2017; Repas, 2008). In Carnivals, biodiesel might be used in all generator, vehicles and other equipment. (b)Removing Scrap-Rubbish: Recycling is processing waste into new products to prevent waste-disposal of potentially useful materials, reduce the consumption of fresh raw materials, reduce energy usage, reduce air pollution and water pollution by decreasing the requirement for habitual waste-disposal and lower greenhouse gas emissions as compared to untouched production. Recycling is a key component of modern waste reduction and is the third component of the "Reduce, Reuse, Recycle" waste hierarchy. Recyclable materials include many kinds of glass, paper, metal, plastic, textiles, and electronics for the perception of removing scrap, rubbish, we allocated the types of the garbage-rubbish came out at the end of carnival. Rubbish will be collected in approved containers. Approved collectors-containers include paper recycling bins, aluminum can recycling bins, plastic recycling bins, battery recycling bins (Reverse vending machine, 2017; Container and Packaging Recycling Update, 2008; Report on Post Consumer Pet Container Recycling Activity, 2005). (c)Traffic And Transportation Opportunities: Green Bus-Shuttle trasportation vehicles are coordinated for coming, transferring at the entertainment location from city centers during the carnival. Rent a Bike-to encourage the people for arriving with their bicycles might be a perception for all cities like the announcement team concept (Young, 2010; Pan, 2012). (d)Consuming Recycled and Organic Products: There are many advantages-benefits of recycling and using organic products. These environmental protectionist dvantages range from reducing costs, conserving energy, reducing pressure on woods, forests and the environmental influences of commercial woodcraft and improving health instructions. Recycled paper products preserve resources and they compose less pollution during manufacturing because the fibers have already been processed once and it reduces solid waste because it diverts usable paper from the waste stream. Producing recycled paper consumes much less total energy than producing unrecycled paper. Organic paper products provide moisture protection, weed control, pest control, plant preservation and other valuable benefits to landscaping and organic farming. In carnivals, all printed materials can be produced in form of recycled materials or organic products such as paper cups, posters, tickets, and handouts (Reverse vending machine, 2017; Container and Packaging Recycling Update, 2008; Report on Post Consumer Pet Container Recycling Activity,2005). (e) Solar Energy: A photovoltaic system is based on the ability of certain materials to convert the radiant energy of the sun into electrical energy. The solar panel is composed of solar cells that collect solar radiation and transform it into electrical energy. Solar panel arrays can be made by connecting a set of panels in series and parallel in order to provide the necessary energy for a given load. The electrical current supplied by a solar panel varies proportionally to the solar radiation (Buying a Photovoltaic Solar Electric System, 2003; Repas, 2008; Khosla, 2017). (f) Carbon Elimination: In order to preserve a high probability of keeping global temperature increase below 2 degrees centigrade, current climate science suggests that atmospheric $\mathrm{CO}_{2}$ concentrations need to peak below 450ppm. This requires global emissions to peak in the next decade and decline to rough $80 \%$ below 1990 levels by the 
year 2050. Such dramatic emissions reductions require a sharp move away from fossil fuel, significant improvements in energy efficiency and a substantial reorganization of our current economic system. This transition can only be achieved by far-reaching national and international climate policies (Kollmus et al., 2008) Carbon elimination is an increasingly popular means of taking action. Individuals research to eliminate their travel emissions and companies claim climate neutrality by buying large quantities of carbon elimination to "disenable" their carbon footprint or that of their products (Kollmus et al., 2008). (g)Recycle Vending Equipments: Waste management refers to the use of a variety of practices to safely handle the household waste stream. Effective waste management requires an integrated approach, the combination of a number of technologies that present options for individuals and communities to consider. Recycling is a key element to minimize the volume of plastics that arrive at landfills and incineration facilities. Virtually every proposed new landfill or incineration facility is opposed by people who live near the site because public consider that they could treat their health and welfare. Incineration is a way to reduce the volume of plastics headed for the landfill. When burned, plastics contribute many pollutants, including heavy metals. When plastics are burned, they produce smoke and release gases. The particulate matter and toxic gases released during burning can be very irritating to people's health and can adversely impact air quality. The most obvious form of pollution associated with plastic packaging is wasted sent to landfills. Plastics are very stable in chemical composition and therefore stay in the environment for a long time after they are discarded if that is shielded from direct sunlight by being buried in landfills.. (Reverse vending machine, 2017; Container and Packaging Recycling Update, 2008; Report on Post Consumer Pet Container Recycling Activity,2005).

\section{DATA AND METHODOLOGY}

\subsection{Multi-Criteria Decision Analysis}

The intial vital point is the MCDA perspective is to absolutely specify the issue and subject or contradiction which meets the decision maker. This situation might consist a condition which needs one off judgment and one which needs multiple, sustainable decisions. The multiple criteria problems are one of the encountered subject for the population and every situations (Belton, 1990). The MCDA model perception is convenient when a nonrational perspective is not suitable, for instance the decison maker determines the decision is too extensive and complicated to conduct and solve intuitively. This includes much more complicated objectives or consits multiple beneficiaries with different opinions. If the destination is one which can be configured as including a classification of alternatives that could be evaluated anomalous various, then the MCDA perception might be convenient (Belton and Vickers, 1993). In this study, the amounts of clean energy varieties are determined. Every variety has a specific price, gain of energy and public relations.

Table 1: Renewable Cost-Energy Analysis

\begin{tabular}{|c|c|c|c|c|}
\hline & Energy per Unit & $\begin{array}{c}\text { Total Energy } \\
\text { per Unit }\end{array}$ & Working Time & $\begin{array}{c}\text { Cost } \\
\text { per Unit }(\$)\end{array}$ \\
\hline Wind & $160 \mathrm{kw} /$ day & $2560 \mathrm{kw}$ & 16 days & 25.000 \\
\hline Piezoelectric & $97 \mathrm{kw} /$ day & $1550 \mathrm{kw}$ & 16 days & 40.000 \\
\hline Biomass & $50 \mathrm{kw} /$ day & $1400 \mathrm{kw}$ & 28 days & 10.000 \\
\hline Solar & $34 \mathrm{kw} /$ day & $952 \mathrm{kw}$ & 28 days & 8.000 \\
\hline
\end{tabular}

There are some constraints; one of them is that the cost has to be smaller than or equal to $\$ 288.000$, the other one is that total public relation value must be greater than or equal to 65 . The objective is to maximize the energy.

A number of panels will be held by $X_{1}, X_{2}, X_{3}$ and $X_{4}$ for wind, piezoelectric, biomass and solar respectively. Public pelation value has taken from public relations department of the company. The data values of the company for the case study is presented in table 1 and table 2

Table 2: Data Table

\begin{tabular}{|c|c|c|c|c|}
\hline & Cost $(\$)$ & Energy $(\mathrm{kW})$ & $\begin{array}{c}\text { Public Relation } \\
\text { Value }\end{array}$ & Number \\
\hline Wind & 25.000 & $2560 \mathrm{~kW}$ & 20 & $\mathrm{X}_{1}$ \\
\hline Piezoelectric & 40.000 & $1550 \mathrm{~kW}$ & 35 & $\mathrm{X}_{2}$ \\
\hline Biomass & 10.000 & $1400 \mathrm{~kW}$ & 15 & $\mathrm{X}_{3}$ \\
\hline Solar & 8.000 & $952 \mathrm{kw}$ & 30 & $\mathrm{X}_{4}$ \\
\hline
\end{tabular}

The problem was modeled into the goal programming concept. Goal programming is a branch of multiobjective optimization which in turn is a branch of multi-criteria decision analysis (MCDA) also known as multiple-criteria decision making (MCDM). This is an optimization programme. It can be thought of as an extension or generalization of linear programming to handle multiple, normally conflicting objective measures. Each of these measures is given a goal or target value to be achieved. Unwanted deviations from this set of target values are then minimized in an achievement function. This can be a vector or a weighted sum dependent on the goal programming variant used. As satisfaction of the target is deemed to satisfy the decision makers, an underlying satisfying philosophy is assumed. The modeling of the problem is;

Maximize $z=2560 * X_{1}+1550 * X_{2}+1400 * X_{3}+952 * X_{4}$ (Energy)

Subject to 
$25000 * X_{1}+40000 * X_{2}+10000 * X_{3}+8000 * X_{4}<=288000$ (Budget Constraint)

$$
\left\{\begin{array}{l}
20, \text { if } \times 1>0 \\
0, \text { otherwise }
\end{array}\right\}^{+}\left\{\begin{array}{l}
35, \text { if } \times 2>0 \\
0, \text { otherwise }
\end{array}\right\}^{+}\left\{\begin{array}{l}
15, \text { if } \times 3>0 \\
0, \text { otherwise }
\end{array}\right\}^{+}\left\{\begin{array}{l}
30, \text { if } \times 4>0 \\
0, \text { otherwise }
\end{array}\right\}^{>=65}
$$

$X_{1}=(0,1,2,3,4,5) ; X_{2}=(0,1,2,3) ; X_{3}=(0,1,2,3 \ldots .15,16) ; X_{4}=(0,1,2,3 \ldots .15,16)$

Meeting the objective, under the constraints was provided with a Visual Basic-Delphi programme and it gives the optimum result. Nonsustainable marketing hurts a company's relationships with consumers and its long-term survival. Changing value systems and the empowerment of consumers will continue to increase the importance of sustainable marketing. In this case, the results are below as table 3.

Table 3: The Table of Result Variable

\begin{tabular}{|c|c|c|c|c|}
\hline & Units & Total Energy $(\mathrm{kw})$ & Total Cost (\$) & $\begin{array}{c}\text { Total } \\
\text { Public Relation }\end{array}$ \\
\hline Wind & 4 & 10240 & 100000 & 20 \\
\hline Piezoelectric & 3 & 4650 & 120000 & 35 \\
\hline Biomass & 2 & 2800 & 20000 & 15 \\
\hline Solar & 6 & 5712 & 48000 & 30 \\
\hline TOTAL & 15 & 23402 & 288000 & 100 \\
\hline
\end{tabular}

Combininig short-term satisfaction with long-term benefits to be successful in marketing environmentally responsible products. Marketing can be a part of the solution: this can contribute to sustainable marketing as an empowered consumer and an enlightened marketer/entrepreneur

\section{FINDINGS AND CONCLUSION}

The beginning with carnival-entertainment facility, X Firm has been assigned a budget for environmental friendly activates with a new green marketing perspective. It is a reasonable move-activity because of being environmentally friendly and preventing global warning are parts of today's marketing trends. Moreover, this study supports and increases householders' awareness of environmental facts. Between the energy alternatives, every energy set has a Public relations value, cost, and gain of energy. The problem is modeled into the goal programming concept. The optimum result is 4 units of wind panel; 3 units of the piezoelectric system, 2 units of biomass system and 6 units of solar panel. This will be set according to the calculations of goal programming programme.

\section{REFERENCES}

Belton, V. (1990). Multiple criteria decision analysis: practically the only way to choose. in LC Hendry and RW Eglese (Eds), Operational Research Tutorial Papers, Operational Research Society, Birmingham.

Belton, V., Vickers, S. (1993). Demystifying DEA - a visual interactive approach based on multiple criteria analysis. Journal of the Operational Research Society, 4489), 883 - 896

Buying a Photovoltaic Solar Electric System: A Consumer Guide (2003). Photovoltaic system components. California Energy CommissionCalifornia Solar Energy Industries Association. http://abcsolar.com/pdf/2003-03-11_500-03-014F.pdf, Access Date: 10.12.2017.

Chen, T. B., Chai, L. T. (2010). Attitude towards the environment and green products: consumers perspective. Management Science and Engineering. 4(2), 27-39.

Cift, B. D., Okutan, H. (2013) Turkey's energy view, clean energy technologies and determination of appropriate energy policy. Journal of Naval Science and Engineering 2013, 9(1), 81-97.

Container and Packaging Recycling Update (2008). Bottle bill resource guide. http://www.bottlebill.org/ Access Date: 10.10 .2017$.

Karl, E. H., Thomas, C. K. (1976). Ecological marketing. American Marketing Association. Pp.168.

Khosla, V. (2012). Scalable electric power from solar energy. Partner, Khosla Ventures, Briefing Paper, https://www.theclimategroup.org/sites/default/files/archive/files/Scalable-Electric-Power-from-Solar-Energy.pdfAccess Date: 12.10 .2017

Kollmus, A., Zink, H., Clifford, P. (2008). Making sense of the voluntary carbon market: a comparison of carbon offset standards. Published by WWF Germany, http://www.wwf.de/fileadmin/fm-wwf/Publikationen-PDF/A_Comparison_of_Carbon_Offset_Standards_lang.pdf. Access Date: 10.12.2017.

Laroche, M., Bergeron, J., Tomiul, M., Barbaro-Forleo, G. (2002). Cultural differences in environmental knowledge, attitudes, and behaviors of Canadian consumers. Canadian Journal of Administrative Sciences, 19(3), 267-283.

Lee, K. (2009). Gender differences in Hong Kong adolescent consumers' green purchasing behavior. Journal of Consumer Marketing, 26(2), 87-96. 
Mahesh, N., Ganapathi, R. (2012). Influence of consumer's socio-economic characteristics and attitude on purchase intention of green products. International Journal of Business and Management, 4(5), 33-37.

McDaniel, S. W., David, H. R. (1993). Strategic green marketing. Journal of Consumer marketing (MCB UP Ltd) 10 (3), 4-10 pp.

Mendleson, N., Michael, J. P. (1995). Using strategic alliances to develop credible green marketing. Journal of Consumer marketing (MCB UP Ltd) 12(2), 4-18 pp.

Mostafa, M. M. (2007). Gender differences in Egyptian consumers' green purchase behaviour: the effects of environmental knowledge, concern, and attitude. International Journal of Consumer Studies, 31(3), 220-229.

Pan, J. (2012). Research on green transportation and transfer system in urban areas. Proceedings of the 2012 International Conference on Automobile and Traffic Science, Materials, Metallurgy Engineering (MMAT 2012), Published by Atlantis Press, Paris, France.

Renewable Energy World, https://www.renewableenergyworld.com/bioenergy/tech/biofuels.html, Access Date: 10.10.2017.

Repas, R. (2008). Sensor sense: Piezoelectric force sensors. http://www.machinedesign.com/sensors/sensor-sense-piezoelectric-forcesensors, Access Date: 10.12.2017.

Reverse vending machine (2017). www.rt-recycling.de Recycling vending machine technology. Access Date: 10.10.2017.

Report on Post Consumer Pet Container Recycling Activity (2005). National Association for PET Container Resources. http://www.plasticsmarkets.org/jsfcode/srvyfiles/napcor_2016ratereport_final_1.pdf, Access Date: 10.10.2017.

Singh, A., Bansal, M. (2012). Green marketing: a study of consumer attitude and environment concern. The Indian Journal of Commerce, 65(2), 273-283.

Young, W., Hwang, K., McDonald, S., Oates, C. J. (2010). Sustainable consumption: green consumer behaviour when purchasing products. Sustainable Development, 18(1), 20-31. 